\title{
Çocuklarda Böbrek Hastalıklarında Tıbbi Beslenme Tedavisi
}

\author{
Medical Nutritional Therapy in Childhood Kidney Diseases
}

\section{Gülhan Samur ${ }^{1}$}

Geliş tarihi/Received: 07.03.2018 • Kabul tarihi/Accepted: 21.11.2018

\section{ÖZET}

Çeşitli hastalıklar nedeniyle böbrek işlevleri ani olarak bozulabilir (akut böbrek yetmezliği) ya da geri dönüşümsüz olarak kaybedilebilir (kronik böbrek yetmezliği). Böbrek hastalıklarına sahip bebek ve çocuklar tedavileri süresince diyetlerinde birçok değişikliklere maruz kalmaktadırlar. Böbrek hastalıklarının tüm evrelerinde büyüme ve gelişmeyi sağlamak için çocukların besin alımı önemlidir. Tıbbi beslenme tedavisi (TBT), tüm yaş gruplarında çocuğun gelişimsel durumu, büyüme potansiyeli ve böbrek işlev kısıtlllıkları göz önüne alınarak bireye özgü olmalıdır. Çocuk hastalarda tedavide amaç, hastalığın progresyonunu yavaşlatmak, komplikasyonları önlemek ve tedavi etmek, büyüme/gelişmeyi ve yaşam kalitesini sağlamaktır. Bu hedeflere ulaşmada tıbbi beslenme tedavisi kritik rol oynamaktadır. Bu derleme makalede, çocukluk çağı böbrek hastalıklarındaki son gelişmeler gözden geçirilerek, güncel beslenme tedavileri uygulamalarına odaklanılacaktır.

Anahtar kelimeler: Akut böbrek yetmezliği, kronik böbrek yetmezliği, tıbbi beslenme tedavisi

\begin{abstract}
A variety of diseases can affect the kidneys leading to a sudden deterioration in renal function (acute kidney injury) or an irreversible deterioration of renal function (chronic kidney disease). Infants and children with kidney diseases face many dietary manipulations throughout their course of treatment. The nutritional intake of the child is especially important in order the ensure optimal growth and development during all stages of renal disease. Diet modification and implementation must be individualized for all age groups, by taking into account the developmental levels, growth potentials and renal functional limitations. Management goals in children with kidney diseases include slowing of disease progression, prevention and treatment of complications, and optimizing growth, development, and quality of life. Nutritional management is critically important to achieve these goals. In this review recent developments in pediatric kidney diseases will be evaluated focusing on dietary measures to improve outcomes.
\end{abstract}

Keywords: Acute kidney injury, chronic kidney disease, medical nutrition therapy

\section{GíRIŞ}

Böbrekler, vücut homeostazisinin korunmasinda elzem olarak görev alan organlardır. Bu önemli görevlerini üre, ürik asit ve kreatinin gibi metabolik atıkları kandan uzaklaştırarak ve üriner boşaltım ile sıvı ve elektrolitlerin dengesini sağlayarak yapmaktadırlar (1). Böbrekler kan basincının kontrolünde, renal/sistemik hemodinamiyi etkileyen renin ve anjiotensin II, kan yapımında görevli eritropoetin gibi bazı hormonların ve kemik metabolizmasını etkileyen $(\mathrm{OH}) \quad \mathrm{D}$ vitamininin

1. İletişim/Correspondence: Hacettepe Üniversitesi, Sağllk Bilimleri Fakültesi Beslenme ve Diyetetik Bölümü, Ankara, Türkiye • E-posta: gsamur@hacettepe.edu.tr (ㄱ) https://orcid.org/0000-0003-0456-4623 
salgılanmasında, peptit hormon katabolizması ve glukoneogenezde de önemli rol oynamaktadırlar (13). Çocukluk çağı böbrek hastalıklarının tedavisinde büyük önemi olan tıbbi beslenme tedavisi (TBT), normal büyüme ve gelişme için gerekli enerji ve besin ögelerini içeren, böbrek işlevlerinin devamını ve korunması sağlayan, komplikasyonları önleyen çocuğa özgü bir beslenme programını içermelidir. Çocukluk çağı böbrek hastalıklarında en uygun beslenme durumunu sağlayarak üremik toksisite, metabolik anormallikler ve klinik malnütrisyon ile kronik morbidite ve mortalite riski azaltılabilmektedir (2-5).

\section{Akut Böbrek Yetmezliği}

Akut böbrek yetmezliği (ABY), böbreklerin işlevlerinin geri dönüşümlü olarak azalması, sıvı elektrolit dengesinin bozulması ve kan üre/ürik asit düzeylerinin artışı ile karakterizedir $(1,5)$. Çocuklarda ABY'ne prerenal (gastroenteritler, hemoraji vb bağlı hipovolemiler, sepsis, antihipertansif ilaçlar, siklosporin, diüretikler vb. ilaçlar), renal (akut glomerulonefrit, akut tübüler nekrozis, hemolitik üremik sendrom, vaskülitler, hipoplazi gibi böbrek ve damarlarının hastalıkları, antibiyotikler, ağır metaller, insektisitler, sitotoksik ajanlar gibi nefrotoksik ilaçlar) ve postrenal etmenler (posterior üretral kapakta obstrüksiyon, tümörler, travma vb.) neden olmaktadır (5-7). ABY tedavisinin hedefi başlangıçta, sıvı dengesini, hiponatremi, hiperkalemi ve yaşamı tehdit edici asidozu iyileştirmeye yöneliktir. Renal replasman tedavisi (RRT), periton diyalizi (PD) ve hemodiyaliz (HD), ciddi persistan hiperkalemi, hipertansiyonla birlikte aşırı sıvı yükü, konjestif kardiyak yetmezlik, pulmoner ödem, ağır üremi, asidoz, hiponatremi, hipokalsemiyi içeren metabolik anormallikler gibi durumların varlığında endikedir. Çocuklarda daha iyi tolere edildiği için periton diyalizi (PD) yöntemi tercih edilmektedir $(6,7)$.

\section{Akut Böbrek Yetmezliğinde Tıbbi Beslenme Tedavisi (TBT)}

ABY'si olan çocuklarda klinik bulgulara ve hastalık derecesine göre yapılacak tıbbi beslenme tedavisi büyük önem taşımaktadır (7). Akut böbrek yetmezliği olan çocuklarda, kas protein sentezinde azalma, artmış hepatik glukoneogenez, anoreksiya, besin ögesi kayıpları gibi nedenlere bağlı olarak katabolizma artmıştır. Çocuklarda beslenme desteğinin amacı yeterli enerji alımını sağlayarak, katabolizma, açlık ve ketoasidozu önlemek, metabolik anormallikleri kontrol altında tutmaktır. ABY olan çocuklarda TBT, klinik tedaviye (konservatif/renal replasman tedavisi), çocuğun büyüme parametrelerine (boy uzunluğu, vücut ağırlığı, ABY gelişmeden önceki ağırlık, kuru ağırlık), biyokimyasal bulgularına (kan sodyum, potasyum, bikarbonat, üre, kreatinin, albümin, glukoz, kalsiyum, magnezyum ve fosfat düzeyleri vb.), gastrointestinal işlevlerine ve beslenme öyküsüne göre belirlenmelidir. ABY olan çocuklarda anoreksiya, kusma ve besin reddi gibi önemli beslenme sorunlarının varlığı oral enteral, enteral veya parenteral beslenme gibi farklı beslenme yollarının tercihini gerektirebilir (3,6-8). Özellikle kusmanın yoğun olduğu başlangıç döneminde kaybedilen suyun yerine konması amacıyla oral olarak sıvı besinler veya enteral beslenme ürünleri verilebilir. Ancak hastalığın akut döneminin uzaması durumunda, diyet tek başına enerji ve besin ögesi gereksinmelerini karşılayamadığı için nazogastrik tüp ile erken dönemde enteral beslenme desteği verilmesi önerilebilmektedir (3). Beslenmeyi tolere edemeyen çocuklarda parenteral beslenme yolu değerlendirilebilir. Ancak çocuklarda gastrointestinal sistem işlevsel olduğu sürece enteral yol kullanılmalıdır $(7,8)$.

\section{ABY'de Enerji ve Besin Ögeleri Gereksinmeleri Enerji}

Akutböbrekyetmezliği olan bebek ve çocuklarda enerji gereksinmesi aynı yaş grubundaki sağlıklı çocukların enerji gereksinmeleri (tahmini ortalama enerji gereksinmesi [EAR] temel alınarak hesaplanmaktadır (Tablo 1). TBT’nin akut döneminde izin verilen sıvı 
miktarı ile önerilen en yüksek enerji alımına ulaşmak güç olduğu için sıvılara glukoz polimerleri (Fantomalt gibi) eklenerek enerji yoğunluğu arttırılabilir. Bebeklerde ise yüksek enerji içeren bebek formülaları (0-6 ay $0.85-1.0 \mathrm{kkal} / \mathrm{mL}, 6-12$ ay $1.0-1.5$ $\mathrm{kkal} / \mathrm{mL}$ ) önerilebilmektedir. Enerji gereksinmelerini karşılamak için 1 yaş üzeri çocuklarda veya vücut ağırlığı 8 kg’ın üzerinde olanlarda pediatrik standart (1 $\mathrm{kkal} / 1 \mathrm{~mL}$ ) veya pediatrik hiperkalorik (1.5 kkal/1mL) enteral beslenme ürünleri kullanılabilir $(1,3,7,8)$.

\section{Protein}

Konservatif tedavi döneminde üremik semptomları azaltmak için protein alımı referans aralığının altına çekilmelidir. Renal replasman tedavisinde ise artan protein kayıplarına bağlı olarak protein alımı arttırılmalıdır. Referans besin ögesi alımları sağlıklı çocuklar için geliştirildiğinden, ABY olan renal replasman tedavisi (RRT) uygulanan çocuklarda kullanımı uygun değildir. Çocuğun vücut ağırlığı, yaşı, biyokimyasal bulguları, RRT şekli göz önüne alınarak tüm gereksinmeleri bireysel olarak ayarlanmalıdır $(3,5,7)$ (Tablo 1).

Tablo 1. Akut böbrek yetmezliği olan çocuklarda enerji ve protein gereksinmeleri (1)

\begin{tabular}{lll}
\hline Tedavi şekli & $\begin{array}{l}\text { Enerji } \\
\text { (kkal/kg/gün) }\end{array}$ & $\begin{array}{l}\text { Protein } \\
\text { (g/kg/gün) }\end{array}$ \\
\hline Konservatif tedavi & $95-120$ & $1.0-2.1$ \\
$0-2$ ay & Kronolojik yaşa uygun EAR & 1.0 \\
$\begin{array}{l}\text { Bebek/çocuk/adolesan } \\
\text { Periton diyalizi }\end{array}$ & $95-120$ & $2.1-2.5^{*}$ \\
$0-2$ ay & Kronolojik yaşa uygun EAR & $1.0-2.5$ \\
Bebek/çocuk/adolesan & & \\
Hemodiyaliz & $95-120$ & $1.0-2.1$ \\
$0-2$ ay & Kronolojik yaşa uygun EAR & $1.0-1.8$ \\
Bebek/çocuk/adolesan & & \\
CRRT & $95-120$ & $2.5-3.0$ \\
$0-2$ ay & Kronolojik yaşa uygun EAR & 2.5 \\
Bebek/çocuk/adolesan &
\end{tabular}

EER: Tahmini ortalama enerji gereksinmesi (estimated average energy requirement), CRRT: Sürekli renal replasman tedavisi

*Diyaliz süresi uzadığında protein gereksinmeyi arttırmak gerekebilir.

Protein miktarı kan üre düzeyine göre belirlenmelidir. Kan üre düzeyi (BUN) $\geq 20$ ve $<30 \mathrm{mmol} / \mathrm{L}$ ise $1 \mathrm{~g} / \mathrm{kg}$ protein içeren diyet verilmelidir. BUN $<20 \mathrm{mmol} / \mathrm{L}$ ise bebeklerde boy yaşına, çocuklarda kronolojik yaşa uygun referans alım düzeyinde (RNI) protein verilmelidir $(3,6,8)$.

TBT’nin başlangıç aşamasında protein gereksinmeyi karşılamak amacıyla sıklıkla nazogastrik tüple enteral beslenme desteği uygulanmaktadır. Enteral beslenme ürünü olarak bebeklerde düşük fosfor ve elektrolit içeriğine sahip standart bebek formülaları kulanılabilir. RRT verildiği dönemde ise kan biyokimyasal bulguları kabul edilebilir düzeyde enerji içeriği yüksek pediatrik enteral beslenme ürünleri (İnfatrini ${ }^{\circledR}$, Similac High Energy ${ }^{\circledR}$ gibi) kullanılabilir. $\mathrm{Bu}$ ürünlerin fosfat içeriği standart whey temelli mamalardan daha yüksek olduğu için kan fosfat düzeyleri düzenli izlenmelidir. Daha büyük çocuklarda, $\geq 1$ yaş ve 8 kg’ın üzerinde standart ve hiperkalorik pediatrik enteral beslenme ürünleri (Pediasure $^{\circledR}$, Nutrini ${ }^{\circledR}$, Pediasure Plus $^{\circledR}$, Fortini $^{\circledast}$, Nephro $^{\circledR}$ ) kullanılabilir. Gereksinmelerini karşlamak için iki ürünün kombinasyonu şeklinde de kullanılabilmektedir (8). 


\section{Siv1}

Konservatif tedavi döneminde sıvı gereksinmesi, genelde vücut yüzeyi alanına göre $400 \mathrm{~mL} / \mathrm{m}^{2}$ veya ortalama $20 \mathrm{~mL} / \mathrm{kg} /$ gün olacak şekilde ayarlanmalıdır. Günlük sıvı gereksinmesi önceki günün idrar çıkışına göre ayarlanmalıdır. RRT'de ise sıvı gereksinmesine ultrafiltrasyonla olan kayıplar eklenerek izlenmelidir. RRT'de ideal sıvı gereksinmesi besin ögesi alımını arttıran sıvılara daha fazla yer verecek şekilde esnek olmalıdir $(3,6,8)$.

\section{Mikro besin ögeleri}

Konservatif tedavi döneminde özellikle potasyum kısıtlaması gerekebilir. Kan potasyum düzeyi ve RRT göre gereksinme yeniden ayarlanmalıdır. Besin ögesi alımını etkileyeceğinden diyetle alımının kısıtlanmasından kaçınılmalıdır. Düşük potasyum içeren besinler konusunda eğitim verilmeli, kan potasyum düzeyi yüksek olduğunda, potasyumdan zengin besinlerin (turunçgiller, muz, meyve suları, kakao ve çikolatalı besinler, patates, yeşil yapraklı sebzeler vb.) diyetten çıkarılması gerektiği belirtilmelidir $(3,8)$.

Hiperfosfotemi durumunda diyetle alınan fosfor (et, tavuk, balık, kurubaklagiller, süt ve süt ürünleri, kuruyemişler, vb.) kısıtlanmalıdır. Diyetle protein alımı azaltıldığında fosfor alımı da kısıtlanmaktadır. Diyettekisodyum alımınıazaltmakiçin tuzlubesinlerin tüketilmemesi ve yemeklere tuz eklenmemesi gerekmektedir. Sıvı alımı kısıtlandığında, sodyum alımının azaltılması, susama hissinin azalmasına yardımcı olabilir $(1,8)$.

ABY'de uzun süreli diyaliz tedavileri yapılacaksa vitamin desteği özellikle iştaha olumlu etkisi nedeniyle suda çözünen vitaminlerin desteği gerekebilmektedir. Sürekli renal replasman tedavisi (CRRT)'nde özellikle folik asit, tiamin ve C vitamini kayıpları olabildiği için suda çözünen vitamin alımları en düşük diyet referans alımı (DRI/DRV) kadar olmalıdır. RRT'de kalsiyum ve magnezyum kayıpları da olabileceği için negatif elektrolit dengesine dikkat edilmelidir. Çinko kaybı anormal oranda gözlemlenirken kan çinko düzeyleri genellikle düşmemektedir. İyileşme dönemindeki ve özellikle ABY’nin başlangıç aşamasında diyet alımı yetersiz olan hastalarda demir desteği gerekli olabilmektedir $(1,6,8)$.

\section{Kronik Böbrek Yetmezliği}

Kronik böbrek yetmezliği (KBY), böbrek işlevleriningeri dönüşümsüz olarak, son dönem böbrek yetmezliğine (SDBY) kadar ilerleyici şekilde bozulmasıdır $(1,5,8)$. Çocuklarda KBY'ye neden olan etmenlerin çoğunluğunu renal displaziler, glomerüler hastalıklar, obstriktüf üropatiler, primer tübüler ve intersisyal hastalıklar, reflü nefropatiler ve konjenital nefrotik sendromlar vb. oluşturmaktadır. KBY’yini, Amerika Birleşik Devletleri'nde Ulusal Böbrek Vakfı'nın Böbrek Hastalığı Sonuçları Kalite Girişimi (NKF/KDOQI/National Kidney Foundation Kidney Disease Outcomes Quality Initiative) beş evrede sinıflandırmaktadır (Tablo 2). Bu sinıflandırma böbreğin olgunlaşması henüz devam ettiğinden 2 yaş altındaki çocuklarda kullanılmamaktadır. KBY evresinin belirlenmesi, üreminin kontrolü için gerekli tıbbi beslenme tedavisinin aşamasını tahmin etmede, elektrolit dengesinin sağlanmasında, enerji ve besin ögeleri gereksinmes oluşturmada önemlidir $(3,5,8)$.

Tablo 2. NKF/KDOQI böbrek yetmezliğinin evrelerinin sinflanması (3)

\begin{tabular}{lll}
\hline Evre & Belirti & $\begin{array}{l}\text { GFH } \\
\left(\mathbf{m L} / \mathbf{d k} / \mathbf{1 . 7 3 2} \mathbf{~ m}^{\mathbf{2}}\right)\end{array}$ \\
\hline 1 & $\begin{array}{l}\text { Böbrek hasarı normal veya } \\
\text { GFH artmış }\end{array}$ & $>90$ \\
2 & $\begin{array}{l}\text { Böbrek hasarı orta veya GFH } \\
\text { azalmış }\end{array}$ & $60-89$ \\
3 & GFH orta derecede azalmış & $30-59$ \\
4 & GFH ciddi derecede azalmış & $15-29$ \\
5 & Böbrek yetmezliği & $<15$ ya da diyaliz \\
\hline $\begin{array}{l}\text { NKF/KDOQI: Ulusal Böbrek Vakfı (National Kidney Foundation) Böbrek } \\
\text { Hastalıları Sonuçların İyileştirme Girişimi (Kidney Disease Outcomes and } \\
\text { Quality Initative), GFH: Glomerüler filtrasyon hızı }\end{array}$
\end{tabular}




\section{Kronik Böbrek Yetmezliğinde Tıbbi Beslenme Tedavisi}

Kronik böbrek yetmezliğinin tedavisi mutlaka diyetisyenin içerisinde olduğu multidisipliner bir ekip tarafından yapılmalıdır. Tedavinin temel amacı çocuğun ve ailesinin yaşam kalitesini arttırmak, hastalığın ilerleyişini durdurmak, komplikasyonları tedavi etmektir (8-11).

KBY olan çocuklarda tıbbi beslenme tedavisinde amaç büyüme gelişme için yeterli enerji ve protein gereksinmeyi sağlamak, renal osteodistrofiden korumak, sıvı ve elektrolit dengeyi sağlamak olmalıdır. KBY'de büyüme geriliği durdurulabilir, ancak büyümeyi yakalamayı başarmak oldukça zordur $(2,4,8)$.

Kronik böbrek yetmezliği olan çocuklarda sıklıkla görülen malnütrisyon, büyüme gelişmeyi olumsuz yönde etkileyen ve mortaliteyi arttıran önemli bir sorundur. Erken dönemde uygulanan tıbbi beslenme tedavisi, KBY olan çocuklarda hem büyümeyi iyileştirmekte hem de mortaliteyi azaltmaktadır. Kaşeksi ve büyüme geriliğinin en önemli nedenleri, yetersiz enerji alımı, üremik toksisite, anemi, artmış inflamatuvar yanıt, metabolik ve endokrin anormallikler olarak siralanabilir $(2,8)$.

\section{Kronik Böbrek Yetmezliği Olan Çocuklarda Beslenme Durumunun Değerlendirilmesi}

KBY olan çocuklarda beslenme ile ilgili parametreleri değerlendirmek, hastalarda görülen sıvı elektrolit dengesizliğinden, ödemden dolayı oldukça zordur. Ayrıca aynı yaş grubundaki çocukların büyümesi ile karşılaştırmakta uygun değildir. Beslenme durumu göstergelerinin izlenme sıklığı, hastanın yaşına, büyüme gelişmesine ve KBY'nin evresine göre değişmektedir. Bu çocuklarda malnütrisyon gelişimini önlemek için Evre 3-4 KBY'de önce 3 ayda $1 \mathrm{kez} / \mathrm{ay}$, daha sonra 6 ayda $1 \mathrm{kez}$ beslenme durumu değerlendirilmelidir. Evre $5 \mathrm{KBY}$ olan 2 yaş altı çocuklarda kontroller ayda bir kez yapılması önerilmektedir. $\mathrm{Bu}$ kontrollerde klinikte diyetisyen tarafından ayrıntılı besin tüketim kayıtları alınmalı ve çocuğa özgü gereksinmeler hesaplanmalıdır $(2,5,8)$. Beslenme durumunun değerlendirilmesinde boy uzunluğu ve vücut ağırlığı için olan büyüme eğrileri kullanılmaktadır. Çocuğun boy uzunluğu normal persentilde ise enerji ve besin ögesi gereksinmeleri o yaşa uygun sağlıklı çocuklar için önerilen gereksinmeler temel alınarak hesaplanmalıdır. Eğer çocuğun boy uzunluğu normal aralığın altında ise mevcut boy uzunluğunun hangi yaşın 50 . persentiline denk geliyorsa o yaş boy uzunluğu yaşı olarak değerlendirilir ve boy uzunluğu yaşına uygun gereksinmeler temel alınırak enerji ve besin ögesi alımları belirlenmelidir. KBY olan çocuklarda sıvı yüklemesi yapmamak için kuru ağırlığı hesaplamak gerekmektedir (1-3,8).

Beden kütle indeksi (BKİ), KBY olan çocuklarda vücut kompozisyonunu değerlendirmede normal çocuklar ile karşılaştırırken uygun bir yöntem değildir. Çocuklarda gövde ve uzuvlarda orantısız bir büyüme, seksüel gelişimde ve lineer büyümede gerilik mevcuttur. Bu nedenle rölatif olarak yağ kütleleri yüksek, kas kütleleri düşük ve artmış santral obezite gözlemlenmektedir $(3,8)$.

\section{Kronik Böbrek Yetmezliğinde Tıbbi Beslenme Tedavisinin İlkeleri}

KBY olan çocuklarda diyet önerileri yaşa ve KBY'nin derecesine (evre) göre şekillendirilmelidir (Tablo 3). Çocukların diyetle yeterli enerji alması sağlanmalı, protein alımı düzenlenmeli ve sıvı elektrolit dengesi sağlanmalıdır. Kalsiyum ve fosfat alımı düzenlenmeli, mikroelementler ve özellikle demir yeterli düzeyde alınmalıdır. $\mathrm{Bu}$ çocuklar genellikle iştahsız olduklarından enerji alımları önerilenin altında kaldığı için modüler enerji destekleri yapılmalıdır. Bebeklerde ve daha küçük çocuklarda ise enteral beslenme ile beslenme desteklenmelidir (2,8-11).

KBY olan bebeklerin beslenmesinde uygun olduğu sürece, anne sütü tercih edilmelidir. KBY olan bebeklerde atı ürünlerin birikmemesi ve normal büyüme ve gelişme sağlanabildiği için formüla seçimini kısıtlamaya gerek yoktur. 
Elektrolitler normal referans değerleri içinde olduğunda ve normal büyüme-gelişme gözlendiğinde standart bebek formülaları kullanılabilinir $(3,8)$.

\section{Enerji}

KBY olan çocukların enerji gereksinmesi yaşıtları ile benzerdir. Özellikle KBY Evre 3 ve Evre 4'te iken enerjinin yeterli düzeyde alımı enerji kaynağı olarak kasların kullanılmasını önlemektedir. Enerji gereksinmesi hesaplanırken çocuğun boy yaşına veya kronolojik yaşa göre ayarlanmalıdır. Kan üre ve potasyum düzeyinin yüksekliği katabolizmanın bir işareti olup bu durumda protein dışı enerji alımının arttırılması gerekmektedir (1-2,5,8). Diyaliz uygulanan çocuklarda ise enerji gereksinmesi hesaplanırken EER değeri kullanılmaktadır. Boy uzunluğu <-2SD olan çocuklarda boy uzunluğu yaşına uygun olan enerji verilmelidir (Tablo 3). Periton Dializi (PD) uygulanan çocuklarda ise diyalizatla glukozun bir kısmı geri emildiği için enerji alımı azaltılmalıdır (3).

Tablo 3. Kronik böbrek yetmezliği olan çocuklarda enerji ve protein gereksinmeleri (1)

\begin{tabular}{|c|c|c|c|c|c|c|}
\hline \multirow{3}{*}{ Yaş grupları } & \multicolumn{6}{|c|}{ Tedavi şekli } \\
\hline & \multicolumn{2}{|c|}{ Konservatif tedavi } & \multicolumn{2}{|c|}{ Peritoneal diyalizi } & \multicolumn{2}{|c|}{ Hemodiyaliz } \\
\hline & $\begin{array}{l}\text { Enerji (kkal/kg/ } \\
\text { gün) }\end{array}$ & $\begin{array}{l}\text { Protein }(\mathrm{g} / \mathrm{kg} / \\
\text { gün) }\end{array}$ & $\begin{array}{l}\text { Enerji (kkal/kg/ } \\
\text { gün) }\end{array}$ & $\begin{array}{l}\text { Protein }(\mathrm{g} / \mathrm{kg} / \\
\text { gün) }\end{array}$ & $\begin{array}{l}\text { Enerji (kkal/kg/ } \\
\text { gün) }\end{array}$ & $\begin{array}{l}\text { Protein }(\mathrm{g} / \mathrm{kg} / \\
\text { gün) }\end{array}$ \\
\hline Prematüre & $110-135$ & $2.5-3$ & $110-135$ & $3.0-4.0$ & $110-135$ & 3.0 \\
\hline $0-2$ ay bebek & $96-120$ & 2.1 & $96-120$ & 2.4 & $96-120$ & 2.2 \\
\hline $3-12$ ay & $72-96$ & $1.5-1.6$ & $72-96$ & 1.9 & $72-96$ & 1.7 \\
\hline $1-3$ yaş & 78-82 & 1.1 & 78-82 & 1.4 & 78-82 & 1.2 \\
\hline 4 yaş-püberte & Alması gereken & $1.0-1.1$ & Alması gereken & 1.3 & Alması gereken & 1.1 \\
\hline Püberte & en düşük enerji & $0.9-1.0$ & en düşük enerji & 1.2 & en düşük enerji & 1.1 \\
\hline Post pübertal & $\begin{array}{c}\text { (boy uzunluğu } \\
\text { <-2 SD ise boy } \\
\text { yaşına uygun } \\
\text { enerji) }\end{array}$ & $0.8-0.9$ & $\begin{array}{c}\text { (boy uzunluğu<-2 } \\
\text { SD ise boy yaşına } \\
\text { uygun enerji) }\end{array}$ & $1.0-1.2$ & $\begin{array}{l}\text { (boy uzunluğu } \\
<-2 \text { SD ise boy } \\
\text { yaşına uygun } \\
\text { enerji) }\end{array}$ & 1.1 \\
\hline
\end{tabular}

SD: Standart sapma

\section{Protein}

Bebek ve küçük çocuklarda protein gereksinmesi büyüme hızı nedeniyle yüksektir. Son yıllarda KBY'de, protein kısıtlamasının böbrek yetmezliğinin ilerleyişini yavaşlatma da önemli bir etkisi olmadığı, büyümeyi yakalamanın daha önemli olduğunu gösteren bilimsel görüşler bulunmaktadır (1,3,10-12).

Protein alımı, büyüme-gelişme, yağsız doku kütlesinin korunması ve nitrojen dengesinin devaminı sağlayacak şekilde ayarlanmalıdır. Büyümeyi olumsuz etkileyen kısıtlamalardan kaçınılarak en az RNI/RDA/PRI'nın \%100'ü olmalıdır (13). Boy uzunluğu $<-2$ SD olan çocuklarda boy uzunluğu yaşına göre RNI/RDA/PRI temel alınmalıdır. Çocuklar referans protein alımlarına enerji alımlarından daha kolay ulaşmaktadırlar. Diyetle alınan proteinin ise \%65-70 biyolojik değeri yüksek protein olmasına da dikkat edilmelidir $(8,13)$.

Diyaliz membranından protein ve aminoasit kayıpları olduğu için çocuklar için RDA’nın \%100’ünün altında olmamalıdır. İdrar ve diyalizat üre nitrojeni, diyalizat protein ve aminoasit, misel nitrojen kayılarının periyodik hesaplamaları gereklidir (6-8,12,13). Hemodiyaliz hastaları için kronolojik yaşa göre DRI/ DRV protein gereksinmesine $0.1 \mathrm{~g} / \mathrm{kg} /$ gün periton diyalizinde ise $0.15-0.35 \mathrm{~g} / \mathrm{kg} / \mathrm{gün}$ protein eklenmesi önerilmektedir. PD uygulanan çocukların protein gereksinmeleri hemodiyaliz (HD) uygulananlardan daha fazla olmakla beraber, küçük yaş gruplarında kayıp daha fazla olmaktadır $(3,8)$. 


\section{Sıvı ve elektrolit dengesi}

Sıvı gereksinmesi, istemsiz sıvı kayıpları, idrar çıkışı ve diyaliz yöntemine bağlı olarak değişmektedir. İstemsiz sıvı kaybı $400 \mathrm{~mL} / \mathrm{m}^{2} /$ gün veya $20 \mathrm{~mL} / \mathrm{kg} /$ gün olarak hesaplanmaktadır. Çocuklarda sıvı yönetimine çok dikkat edilmesi gerekmektedir. Aşırı sıvı yüklenmesi kardiyomiyopatiye neden olmaktadır. Sıvı kısıtlaması gerektiği durumlarda, pratikte ilaçların sıvı formları yerine tablet formları kullanılmalı, sıvı formda olan besinler katı formda aynı besin grubunda olan besinler ile yer değiştirilmelidir. Susamayı önlemek için de tuz alımının azaltılması ve iyi bir ağız bakımı dikkate alınmalıdır $(2,8)$.

Bebeklerde üriner konsantrasyon kapasitesinin azalması, sodyum kaybının olduğu renal displazi ve obstrüktif üropati KBY’nin en önemli nedenleridir. Sodyum deplesyonu ekstrasellüler sıvı volumünün kontraksiyonuna,böbrekişlevlerindegeridönüşümsüz bozulmalara ve büyüme gelişme geriliğine neden olmaktadır $(8,11)$. Bu durumda bebek besinlerine tuz eklenmesi veya ilaç olarak tedavi planına eklenmesi gerekmektedir. Büyüme durumu iyileşinceye kadar hipertansiyon, periferal ödem, hipernatremi oluşturmayacak şekilde sodyum miktarı 4-6 mmol/kg/ gün'e kadar arttırılabilir. Genellikle poliüri görüldüğü için besinlerin sıvı formda alınması ve ekstra su alımı gerekmektedir. Primer böbrek hastalıklarından dolayı ortaya çıkan hipertansiyon durumlarında ise aksine sodyum alımının kısıtlanması yararlı olabilir. $\mathrm{Bu}$ durumda tuzsuz diyet verilmelidir (11-16).

Evre 4-5 KBY'de glomerül fitrasyon hızı (GFH) azaldığından, sodyum ve sıvı retansiyonu çoğunlukla gözlemlenmektedir. Sıvı kısıtlaması, GFH <15 mL/ $\mathrm{dk} / 1.73 \mathrm{~m}^{2}$ olduğunda, idrar çıkışına ve ödem durumuna göre yapılmalıdır. PD uygulanan çocuklarda ve özellikle poliürik bebeklerde, sodyum kayıplarından dolayı hiponatremi (serum sodyum <130 mmol/L) görülebilmektedir. Bu durumda diyetle sodyum alımı arttırılmalıdır. Hipertansif HD uygulanan çocuklarda ise diyaliz seansları arası vücut ağırlığında ki artış nedeni tuz alımı ve aşırı su tüketimi ile ilgilidir. Sodyum alımının kabul edilebilir düzeyi 1-3 mmol/kg/gün arasındadır (16-19).

Evre 1-3 KBY olan çocukların çoğunda potasyum homeostazı vardır. Eğer hiperpotasemi gözlenirse, potasyumdan kısıtlı diyete geçmeden önce ACE inhibitörleri gibi ilaçların etkisi, metabolik asidoz ve katabolizma gibi durumlar doğrulanmalıdır. Evre 5 KBY olan çocuklarda hiperpotasemide potasyumdan kısıtlı diyet gerekmektedir. Hiperpotasemi kalbi etkilediği için en tehlikeli elektrolit bozukluğudur $(2,8,20-24)$.

KDOQI, bebekler ve küçük çocuklar için 40 ila 120 mg/ kg/gün ve daha büyük çocuklar için 30-40 mg/kg/gün ile potasyum alımının kısıtlanmasını önermektedir. Anne sütünün potasyumu doğal olarak düşüktür ve KBY’li bebekler için en iyi besindir. Anne sütü mevcut değilse, potasyumu düşük formüller kullanılmalıdır. Gerekirse, formüller potasyum içeriğini daha da düşürmek için bir potasyum bağlayıcılar ile ön işleme tutulabilir (20-24).

İdrar çıkışı iyi olan bir çocuk daha serbest bir potasyum alımını tolere edebilir. Anürik veya böbrekleri çalışmayan bebek ve çocukların diyet potasyumundaki değişiklik kaçınılmazdır. PD alanlarda ılımlı potasyum alımına izin verilmektedir. HD tedavisi potasyumu temizlemede çok etkili olmasina rağmen HD uygulanan çocuklarda hiperkalemi ile ilgili sorunları en aza indirmek için diyet potasyum alımına ilişkin öneriler verilmelidir. Potasyum alımı konusundaki öneriler her bireye özel olmalıdır $(1,8)$.

Bebek ve çocuklarda asit-baz dengesi çok önemlidir. Metabolik asidoz, hiperpotasemi ve kemik demineralizasyonuna neden olabildiğinden büyüme geriliği ile sonuçlanabilmektedir. Asidoz sodyum bikarbonat tedavisi ile düzeltilmektedir. Genellikle Evre 5 KBY'ne kadar sodyum retansiyonuna neden olmaz. Kan basincı üzerine çok az etkisi olup, diyet sodyum alımı hesabına katılmasına gerek yoktur. Kronik asidoz insülin rezistansına neden olup, büyüme geriliğine yol açmaktadır (25-27). 
Kronik Böbrek Yetmezliği ve Mineral Kemik Hastalıkları

Erken evre böbrek hastalığında, 1,25 dihidroksikolekalsiferolün $\quad(1,25(\mathrm{OH}) 2 \mathrm{D} 3)$ sentezi ve fosfor atımındaki yetersizliği, sekonder hiperparatiroidizm ve renal osteodistrofinin ortaya çıkmasına neden olmaktadır (28-30). Hiperfosfatemi kemik deformasyonlarının geç göstergesi olarak bilinir. KBY olan hastalarda D vitamini yetersizliği kalsitriolün supresyonunu hızlandırır. Bundan dolayı, KBY hastalarında erken dönemde D vitamini düzeyleri değerlendirilmeli ve gerekiyorsa ek olarak verilmelidir. Tedavide, diyette yüksek fosfor içeren besinler ve içecekler kısıtlanmalı (öncelikle süt ürünleri, çikolata, fındık ve kola gibi asitli içecekler), D vitamini (1,25(OH)2D3) ve kalsiyum desteği yapılmalı ve öğunlerle birlikte alüminyum ve magnezyum içermeyen fosfor bağlayıcı ajanlar (kalsiyum karbonat, asetat, glubiyonat ve/veya sevelamer hidroklorid vb.) alınmalıdır. Bebeklerde, whey/kazein oranı 60/40 olan formüla seçimi yapılabilir, ancak bu mamaların fosfor içeriği düşük olduğu için büyüyen bebekler için yeterli fosforu sağlamada yetersiz kalabilir. Normal plazma kan fosfor değerlerinden daha düşük kan fosfor düzeyine sahip KBY olan bebek hastalarda fosfor içeriği yüksek olan ürünle değişim yapmak veya fosfor desteğine başlamak gerekebilir $(1,2,8)$.

Diyaliz uygulanan çocuklarda fosfor kısıtlanmaktadır. Çocuklarda daha düşük hacimli diyalizatlar kullanıldığı için fosforun vücuttan uzaklaştırılması azalmaktadır. $\mathrm{Bu}$ nedenle diyetlerindeki fosfor kısıtlaması devam etmektedir (1).

\section{Kronik Böbrek Yetmezliği-Hipertansiyon ve Kardiyovasküler Hastalıklar}

Kardiyovasküler anormallikler, KBY'nin erken evrelerinde gelişip, son dönem KBY evresine kadar ilerlemektedir. Renal yetersizlikte bilinen risk etmenleri sol ventriküler hipertrofi (LVH), hiperlipidemi, hipoalbüminemi, hipertansiyon (HT), mineral metabolizmasındaki bozukluklardır. HT ve artan volüm çocuklarda LVH'ye neden olmaktadır. Damar duvarlarındaki kalınlaşma ve sertlik kalsiyum, fosfor ve PTH düzeylerinde anormal yükselmeye neden olmaktadır (8,31-33).

Hipertansiyon, son dönem KBY'de renin-anjiyotensinaldosteron aktivasyonu ve sıvı yükünden dolayı sıklıkla karşılaşılan bir durumdur. Hiperparatiroidizm de aynı zamanda gelişebilmektedir. Tedavisinde tuz kısıtlaması yapılmaktadır. Kilolu olan çocuklarda beraberinde izlenerek, egzersiz ve ağırlık kaybı önerilmektedir $(8,32)$.

\section{Kronik Böbrek Yetmezliği- Anemi}

Anemi, KBY olan çocuklarda GFH 60 mL/dk/1.73m²’nin altına düştüğünde gözlenen yaşam kalitesini, egzersiz kapasitesini azaltan, kardiyovasküler hastalık ve morbidite riskini arttıran bir sorundur $(1,2,8,33)$. Hasarlı böbreğin yetersiz eritropoetin üretiminden dolayı normokromik, normositik anemi gözlenmektedir. Tedavide diyet, yaşa ve cinsiyete göre önerilen demir, folik asit, $C$ vitamini ve $B_{12}$ vitamininden zengin besinler ile desteklenmelidir. Diyetle demir alımının yetersiz olduğu durumlarda ek demir alımı önerilmektedir. Evre 5 KBY'de intravenöz demir tedavisi önerilmektedir. Hem olmayan demirin de emilimi açısından C vitamini desteği ile beraber verilmesi önerilmektedir. Aşırı destekten kaçınılmalıdır. Yemeklerden 1-2 saat sonra 2-3 mg/kg/ gün elemental demirin 2-3 doza bölünerek verilmesi önerilmektedir (33-37).

KBY olan çocuklarda diğer vitamin ve mineral gereksinmeleri hesaplanırken önerilen alım düzeyleri temel alınmalı ve ek yapılmadan önce serum düzeyleri kontrol edilmelidir $(2,8)$.

\section{Böbrek Nakli (Transplantasyon) ve Tıbbi Beslenme Tedavisi}

Son dönem böbrek yetmezliğinde olan pediatrik hastaların son tedaviprogramı transplantasyondur. Bu tedavi seçeneği çocuklarda büyümeyi yakalamayı ve normal büyüme/gelişme firsatını sağlamaktadır $(2,8)$. Transplantasyon sonrası dönemde oral beslenmeye 
başlandığı zaman tıbbi beslenme tedavisi önerileri kişiye özeldir. Transplantasyon sonrası agresif olarak hemen nütrisyon desteği başlanmalıdır (8). Diyet kısıtlamaları biyokimyasal bulgular kontrol edilerek biraz daha açılabilir. Aldığı ve çıkardığı sıvı izlenir (1-3,8). Hipertansiyon ve dislipidemi gözlemlenebilir. Hipertansiyon diyette tuz kısıtlaması ile kontrol altına alınabilmektedir. Uzun süre kortikosteroid tedavisi hiperlipidemiye yol açmaktadır. Diyet yağının modifikasyonu ile beraber antioksidan sebze ve meyvelerin önerilmesi, orta düzeyde fiziksel aktivite ile beslenmenin desteklenmesi önerilebilir (38-40).

\section{SONUÇ VE ÖNERİLER}

Böbrek hastalıklarının tüm evrelerinde uygun büyüme ve gelişmeyi sağlamak için çocukların besin

\section{KAYNAKLAR}

1. Royle J. Kidney diseases. In: Shaw V, editör. Clinical Paediatric Dietetics. 4th ed. Oxford: Wiley Blackwell Publications; 2015.p. 242-81.

2. Oleh MA. Chronic kidney disease and dietary measures to improve outcomes. Pediatr Clin N Am 2019;66: 24767.

3. KDOQI Clinical Practice Guideline for Nutrition in Children with CKD:2008 Update. Am J Kidney Dis 2009;53: S1-124.

4. Eriksson JG, Salonen MK, Kajantie E, Osmand C.Prenatal growth and CKD in older adults: longitudinal findings from the Helsinki Birth Cohort Study, 1924-1944. Am J Kidney Dis 2018;71(1):20-6.

5. Köksal G, Gökmen H. Çocuk Hastalıklarında Beslenme Tedavisi. Ankara, Hatiboğlu Yayınevi;2000. s.1-957.

6. Walters S, Porter C, Brophy PD. Dialysis and pediatric acute kidney injury: choice of renal support modality. Pediatr Nephrol 2009;24:37-48.

7. Coleman JE, Watson AR. Nutritional support for the child with acute renal failure. J Hum Nutr Diet 1992;5:99-105.

8. Phelan LA. Kidney diseases. In: Samour P, King K, editors. Essentials of Pediatric Nutrition. USA:Jones and Bartlett Publishers; 2013. p.197-201.

9. Graciolli FG, Neves KR, Barreto F, Barreto DV, Dos Reis LM, Canziani ME, et al. The complexity of chronic kidney disease-mineral and bone disorder across stages of chronic kidney disease. Kidney Int 2017;91(6):143646. alımı önemlidir. Tıbbi beslenme tedavisi tüm yaş gruplarında bireye özgü olmalı ve çocukların böbrek işlevleri, büyüme ve gelişme durumları dikkate alınarak yeterli ve uygun bir diyet hazırlanmalıdır. Çocuk hastalarda tıbbi beslenme tedavisinde amaç, büyüme gelişme için yeterli enerji ve protein gereksinmeyi sağlamak, renal osteodistrofiden korumak, sıvı ve elektrolit dengesini sağlamak olmalıdır ve sonuç olarak çocuklarda anemi ve üreminin izlemi böbrek hastalıklarının progresyonu ve kontrolünde, çocukların normal gelişiminde önemli rol oynamaktadır.

Çıkar çatışması - Conflict of interest: Yazarlar çıkar çatışması olmadığını beyan ederler. - The authors declare that they have no conflict of interest.

10. Wheeler DC, Winkelmayer WC. KDIGO 2017 clinical practice guideline update for the diagnosis, evaluation, prevention, and treatment of chronic kidney diseasemineral and bone disorder (CKD-MBD) foreword. Kidney Int Suppl 2017;7(1):1-59.

11. Nomura K, Asayama K, Jacobs L, Thijs L, Staessen JA. Renal function in relation to sodium intake: a quantitative review of the literature. Kidney Int 2017;92(1):67-78.

12. Scientific Advisory Committee on Nutrition (SACN) Dietary Reference Values for Energy. London: TSO, 2011;19-21.

13. Department of Health Report on Health and Social Subjects. Dietary Reference Values for Food, Energy and Nutrients for the United Kingdom. London: The Stationery Office; Report No.:41, Rep Health Soc Subj (Lond). 1991;41:1-210.

14. Klein C, Moser-Veillon PB, Schweitzer A, Douglass LW, Reynolds HN, Patterson KY, et al. Magnesium, calcium, zinc and nitrogen loss in trauma patients during continuous renal replacement therapy. J Parenter Enteral Nutr 2002;26:77-93.

15. Berger MM, Shenkin A, Revelly JP, Roberts E, Cayeux MC, Baines M, et al. Copper, selenium, zinc and thiamine balances during continuous venovenous hemodiafiltration in critically ill patients. Am J Clin Nutr 2004;80:410-16.

16. Shenoy M, Plant N. Management of acute renal failure in children. Paediatr Child Health 2008;18:375-80. 
17. Jayaraman R, Van der Voort J. Principles of management of chronic kidney disease. Paediatr Child Health 2010;20:291-6.

18. Group KK. KDIGO clinical practice guideline for lipid management in chronic kidney disease. Kidney Int Suppl 2013;3:259-305.

19. Rees L, Shaw V. Nutrition in children with CRF and on dialysis. Pediatr Nephrol 2007;22:1689-702.

20. Rashid R, Neill E, Smith W, King D, Beattie TJ, Murphy $\mathrm{A}$, et al. Body composition and nutritional intake in children with chronic kidney disease. Pediatr Nephrol 2006;21:1730-8.

21. Kari JA, Gonzalez C, Ledermann SE, Shaw V, Rees L. Outcome and growth of infants with severe chronic renal failure. Kidney Int 2000; 57: 1681-7.

22. Chaturvedi S1, Jones C. Protein restriction for children with chronic renal failure. Cochrane Database Syst Rev. 2007; 17;(4):CD006863.

23. Whyte DA, Fine RN. Chronic kidney disease in children. Pediatr Rev 2008;29:335-41.

24. Secker D. Evaluation of growth and nutritional status: assessing nutritional intake, growth and body composition. KDOQI Clinical Practice Guideline for Nutrition in Children with CKD: 2008 Update. Am J Kidney Dis 2009;53(Suppl 2):1-17.

25. Haffner D, Schaefer F, Nissel R, Wühl E, Tönshoff B, Mehls O.For the German study group for growth hormone treatment in chronic renal failure. Effect of growth hormone on the adult height of children with chronic renal failure. N Engl J Med 2000;343:923-30.

26. Haycock GB. The influence of sodium on growth in infancy. Pediatr Nephrol 1993;7:871-5.

27. Treatment of Adults and Children with Renal Failure. Standards, Audit Measure, 3rd ed. London: Royal College of Physicians of London and the Renal Association, 2002;21-45.

28. Milliner DS, Zinsmaster AR, Lieberman E, Landing B. Soft tissue calcification in pediatric patients with end stage renal disease. Kidney Int 1990;38:931-6.
29. Rees L, Schroff RC. Phosphate binders in CKD: chalking out the differences. Pediatr Nephrol 2010;25:385-94.

30. Schmitt CP, Mehls O. Mineral and bone disorders in children with chronic kidney disease. Nat Rev Nephrol 2011;7:624-34.

31. Salt and health scientific advisory committee on Nutrition, 2003. London: The Stationery Office. Available at: www.sacn.gov.uk. Accessed April, 2012.

32. Shroff R, Weaver DJ, Mitsnefes MM. Cardiovascular complications in children with chronic kidney disease. Nat Rev Nephrol 2011;7:642-9.

33. Norman LJ, Coleman JE, Watson AR. Nutritional management in a child on chronic peritoneal dialysis: a team approach. J Hum Nutr Diet 1995;8:209-13.

34. Schmitt CP, Zaloszyc A, Schaefer B, Fischbach M. Peritoneal dialysis tailored to pediatric needs. Int J Nephrol. 2011;9:402-67.

35. Wong CS, Hingorani S, Gillen DL, Sherrard DJ, Watkins SL, Brandt JR, et al. Hypoalbuminemia and risk of death in pediatric patients with end-stage renal disease. Kidney Int 2002;61:630-7.

36. Srivaths PR, Wong C, Goldstein SL. Nutrition aspects in children receiving maintenance hemodialysis: impact on outcome. Pediatr Nephrol 2009;24:951-7.

37. Kalantar-Zadeh K, Cano NJ, Budde K, Chazot C, Kovesdy $\mathrm{CP}$, Mak RH, et al. Diets and enteral supplements for improving outcomes in chronic kidney disease. Nat Rev Nephrol 2011;7:369-84.

38. Lukaszyk E, Lukaszyk M, Koc-Zorawska E, Tobolczyk J, Bodzenta-Łukaszyk A, Małyszko J, et al. Iron status and inflammation in early stages of chronic kidney disease. Kidney Blood Press Res 2015;40(4):366-73.

39. Rees L, Jones H. Nutritional management and growth in children with chronic kidney disease. Pediatr Nephrol 2013;28(4):527-36.

40. Holmes KW, Kwiterovich PO Jr. Treatment of dyslipidemia in children and adolescents. Curr Cardiol Rep 2005;7:445-56. 